\title{
Haem oxygenase augments porcine granulosa cell apoptosis in vitro
}

\author{
Tatsuya Harada, Hideki Koi, Toshiro Kubota and Takeshi Aso \\ Comprehensive Reproductive Medicine, Graduate School, Tokyo Medical and Dental University, 1-5-45, Yushima, Bunkyo-ku, Tokyo 113-8519, Japan \\ (Requests for offprints should be addressed to Tatsuya Harada; Email address: t.harada.gyne@tmd.ac.jp)
}

\begin{abstract}
Haem oxygenases produce carbon monoxide, which, like nitric oxide, is a gaseous messenger molecule that is one of several important survival factors in ovarian follicles. However, little is known about the expression and possible functions of these enzymes in granulosa cells. The purpose of this study was to investigate the expression and possible role of haem oxygenases in porcine granulosa cells (PGCs). We obtained frozen sections of porcine ovaries and PGCs from ovarian follicles of various sizes by needle aspiration, and examined the expression of haem oxygenase-1 (HO-1; inducible type) and HO-2 (constitutive type) in PGCs by immunohistochemistry, RT-PCR, western blotting and flow cytometry. Both types of haem oxygenase were identified in PGCs throughout follicular development, but HO-1 was expressed primarily in granulosa cells in atretic follicles. We also investigated the effect of haem oxygenases on apoptosis of granulosa cells (flow cytometry to detect subdiploid DNA fluorescence) and on expression of Fas ligand (quantitative analysis of
\end{abstract}

western blotting and flow cytometry). In tightly bound PGCs, the mean proportion of apoptotic cells treated with $1 \mu \mathrm{M}$ haemin (a haem oxygenase substrate) was approximately 1.7-fold greater than that in untreated controls, and zinc protoporphyrin IX (ZnPP IX; a haem oxygenase inhibitor) completely inhibited the increase in apoptosis induced by haemin in 24-h culture. Conversely, in weakly associated PGCs, the proportion of apoptotic cells was not altered by haemin. The quantity of Fas ligand protein was increased in a dose-dependent manner in tightly bound PGCs treated with haemin compared with controls, and the haemin-induced increase in Fas ligand protein was inhibited by ZnPP IX. Thus we identified inducible HO-1 and constitutive HO-2 in PGCs throughout follicular development, and we conclude that products of reactions catalysed by haem oxygenases are likely to be important autocrine/paracrine factors that regulate apoptosis in PGCs.

Journal of Endocrinology (2004) 181, 191-205

\section{Introduction}

Carbon monoxide (CO) is a gaseous messenger molecule that has diverse cellular functions (Otterbein \& Choi 2000). It has a role similar to that of nitric oxide (NO) in some organs: it is considered to be a neurotransmitter like NO in the central nervous system (Costa et al. 1996, Kim \& Rivier 2000), and both CO and NO stimulate the action of soluble guanylate cyclase, thereby promoting smooth muscle relaxation and vasodilatation in the cardiovascular system (Villamor et al. 2000). CO is produced endogenously, mainly from the degeneration of haem by haem oxygenases (Maines 1988).

Haem oxygenases are the rate-limiting enzymes in haem degradation, catalysing the cleavage of the haem ring to form free iron, carbon monoxide and biliverdin. Biliverdin is subsequently converted to bilirubin by biliverdin reductase, and free iron is promptly sequestered into ferritin. Three distinct variants of haem oxygenases have been identified in humans. HO-1 is an inducible enzyme, the synthesis of which is elicited by numerous stimulants such as cytokines, heat shock, heavy metals, hypoxia, endotoxins and oxidants that induce inflammatory damage (Yoshida et al. 1988, Eyssen-Hernandez et al. 1996, Carraway et al. 1998, Otterbein \& Choi 2000, Panchenko et al. 2000, Stuhlmeier 2000). In contrast, HO-2 is constitutively expressed and is concentrated mostly in the brain and testes (McCoubrey et al. 1992, Otterbein \& Choi 2000). HO-3 is also localized primarily in the brain, although its enzymatic activity is lower than that of the other isoenzymes (McCoubrey et al. 1997). HO-1 reduces vasoconstriction and inhibits cell proliferation during vascular injury in pig arteries (Duckers et al. 2001). HO-2 protein is highly expressed in large and small blood vessels of newborn pig cerebrum and its product, CO, contributes to vasodilatation (Leffler et al. 1999). Betamethasone upregulates $\mathrm{HO}-2$ protein in endothelial cells of the cerebral microvascular of newborn pigs (Parfenova et al. 2001). Thus the roles of HO-1 and $\mathrm{HO}-2$ in various physiological phenomena have been investigated in porcine models.

In granulosa cells, the NO exerts an inhibitory effect through a cGMP-dependent pathway (Chun et al. 1995). Some investigators have also found that the $\mathrm{NO} /$ nitric 
oxide synthase (NOS) system inhibits steroid production and $\mathrm{P} 450$ aromatase activity in human luteal granulosa cells and in porcine granulosa cells (PGCs) (Van Voorhis et al. 1994, Masuda et al. 1997). As CO and NO have similar cellular functions in several organ systems, including the central nervous system (Kim \& Rivier 2000) and the cardiovascular system (Villamor et al. 2000), the $\mathrm{CO} /$ haem oxygenase system also may be involved in the follicular development of the ovaries.

During follicular development, the majority of ovarian follicles are destined to undergo atresia, which is known to occur via apoptosis throughout female life (Tilly et al. 1991, Kaipai \& Hsueh 1997). Apoptosis of follicular cells occurs at all stages of follicle development, and is regulated by several intraovarian factors, including tumour necrosis factor (TNF) $-\alpha$, interleukin (IL) -6 , and gonadotrophin releasing hormone (Gorospe et al. 1992, Billig et al. 1993, Santana et al. 1995, Kaipai et al. 1996). In addition, overexpression of $\mathrm{Bcl}-2$ in follicular cells inhibits cell apoptosis and increases the frequency of germ cell tumours in ageing animals (Hsu et al. 1996). Therefore, follicular cell apoptosis is also important for normal ovarian development.

Haem oxygenase has various cellular functions in endocrine organs. In rat cultured pancreatic islets, it provides a protective role against the actions of IL- $1 \beta$ that induce cell apoptosis and inhibit insulin release (Ye \& Laychock 1998). In rat adrenals, treatment with tin protoporphyrin IX (SnPP IX), a haem oxygenase inhibitor, attenuates serum corticosterone concentrations by inhibiting the activities of both microsomal $21 \alpha$-hydroxylase and mitochondrial 11ß-hydroxylase (Maines \& Trakshel 1992). In rat testes, SnPP IX also inhibits the activities of cytochrome P450 and microsomal 17 $\alpha$-hydroxylase (Maines \& Trakshel 1992). Furthermore, because cadmium chlorideinduced HO-1 augmented the rate of apoptosis of premeiotic germ cells, the $\mathrm{CO} / \mathrm{haem}$ oxygenase system was considered to regulate homeostasis of spermatogenesis under conditions of stress (Ozawa et al. 2002). In ovaries, haem oxygenase may have a regulatory role during oogenesis. However, the possibility that haem oxygenase might stimulate steroidogenesis in rat ovary was reported only recently (Alexandreanu \& Lawson 2003), and little is known about the possible functions of haem oxygenases in the female reproductive organ.

In the present study, we investigated the expression of inducible type (HO-1) and constitutive type (HO-2) haem oxygenases in PGCs by means of immunohistochemistry, reverse transcription-polymerase chain reaction (RT-PCR), western blotting and flow cytometry. Furthermore, we examined these haem oxygenases separately in two subpopulations of PGCs, weakly associated and tightly bound, which are distinguished by size and have different functional characteristics (Marrone \& Crissman 1988, Howard \& Ford 1994, Duda et al. 1999). Subsequently, we investigated the effects of haem oxygenase substrate and haem oxygenase inhibitor on granulosa cell apoptosis, using flow cytometry to measure subdiploid DNA fluorescence, and on the expression of Fas ligand, using quantitative analysis of western blotting and flow cytometry immunocytochemistry. Our results demonstrated that both haem oxygenases, inducible and constitutive, were expressed throughout follicular development and that haem oxygenase products augmented the expression of Fas ligand protein and apoptosis in PGCs.

\section{Materials and Methods}

\section{Immunohistochemistry}

Serial frozen sections ( $8 \mu \mathrm{m}$ thick) of porcine ovary samples obtained from 4-6-month-old Yorkshire pigs at a local slaughterhouse were mounted onto silane-coated slides, and then fixed in acetone at $4{ }^{\circ} \mathrm{C}$ for $15 \mathrm{~min}$. Thereafter, sections were treated with $3 \%$ hydrogen peroxide in absolute methanol for $10 \mathrm{~min}$ in order to block endogenous peroxidase activity. After a washing with PBS, pH 7·2, the sections were preincubated for $30 \mathrm{~min}$ at room temperature with Dulbecco's PBS (D-PBS; Takara, Tokyo, Japan) containing 5\% normal goat serum, to prevent non-specific binding of the antibodies. They were then incubated with anti-HO-1 (1:100) or anti-HO-2 (1:200) polyclonal antibody (Stressgen, Victoria, Canada) for $1 \mathrm{~h}$ at room temperature. After washing with PBS, the sections were incubated for $30 \mathrm{~min}$ at room temperature with Histofine simple stain PO (Nichirei Co., Tokyo, Japan). The histochemical reaction method for detecting peroxidase activity was carried out as described in a previous report (Harada et al. 2002). The immunostained sections were counterstained with Mayer's haematoxylin. The specificity of these antibodies in pig tissues, and their lack of cross-reactivity, have already been reported (Parfenova et al. 2001) and we reconfirmed their specificities by band size in western blotting analysis. Negative controls were prepared by replacing the primary antibody with an appropriately diluted normal rabbit serum.

\section{Cell collection}

Porcine granulosa cells were collected from 4-6-monthold Yorkshire pigs and cultured as described previously (Masuda et al. 1997). PGCs were isolated from different stages of follicles, classified as small $(<2 \mathrm{~mm})$, medium (3-5 mm), or large $(>6 \mathrm{~mm})$, by needle aspiration. For protein and mRNA extraction, cells were washed twice with D-PBS, and then stored at $-80^{\circ} \mathrm{C}$ until required for use. For immunocytochemistry using flow cytometric analysis, cells were incubated with $2 \mathrm{mg} / \mathrm{ml}$ collagenase type 1 (Sigma) and $100 \mu \mathrm{g} / \mathrm{ml}$ deoxyribonuclease (DNase) (Sigma)/D-PBS containing 0.133 mg/ml calcium dichloride for $20 \mathrm{~min}$ at $37^{\circ} \mathrm{C}$ for dissociation, and washed twice with D-PBS before the next procedure. 
To determine the effect of haem oxygenase on granulosa cell apoptosis, PGCs were isolated from medium follicles $(3-5 \mathrm{~mm})$ by the needle aspiration method. After enzymatic dissociation as described above, the cells were washed and then suspended in Dulbecco's modified Eagle's medium (DMEM) (Life Technologies Inc.) containing 10\% FCS (Nichirei Co.) and 1\% antibioticantimycotic solution, containing $10000 \mathrm{U} / \mathrm{ml}$ penicillin $\mathrm{G}, 10000 \mu \mathrm{g} / \mathrm{ml}$ streptomycin sulphate and $25 \mu \mathrm{g} / \mathrm{ml}$ amphotericin B (Life Technologies Inc.). Cells were seeded on $10 \mathrm{~cm}$ culture dishes and preincubated for $48 \mathrm{~h}$ at $37{ }^{\circ} \mathrm{C}$ in a humidified $95 \%$ air-5\% $\mathrm{CO}_{2}$ incubator before the examination. On the day of experiment, the medium was changed and the cells were incubated with various compounds in serum-free, phenol-red-free DMEM.

\section{Separation of two subpopulations of PGCs}

Porcine granulosa cells were enzymatically dissociated as described above, and then separated by filtration on a $0.8 \mu \mathrm{m}$ nylon mesh filter. Weakly associated PGCs passed through the filter, but whole PGCs did not. Both groups of cells were fixed with 4\% paraformaldehyde/D-PBS and were then used to set the gate for flow cytometry experiments, separating the two subpopulations of PGCs: the two subpopulations have differential channels of forward scatter, which reflects cell size (Marrone \& Crissman 1988). A Beckton Dickinson fluorescenceactivated cell sorter (FACS) Calibur machine was used for analysis, after calibration with CaliBrite beads.

\section{$R N A$ isolation and RT-PCR}

Total RNA was isolated from PGCs using RNeasy mini kits (Qiagen, Valencia, CA, USA) in accordance with the manufacturer's instructions. The quantity of extracted total RNA was determined by spectrophotometry at 260 and $280 \mathrm{~nm}$. Complementary DNA was prepared from $1 \mu \mathrm{g}$ DNase-treated RNA using the SuperScript First-Strand Synthesis System (Life Technologies Inc.), and one-tenth of the mixture was treated with $\mathrm{RT}$ and used as the template for PCR. The primer sequences for porcine HO-1 were designed according to published cDNA sequences. The forward 5'-CAGCCCAACAGCATGCC CCAG-3' (87-107) and the reverse 5'-CGTAGCGC TTGGTGGCCTGCG-3' (417-397) primers were used to amplify a $331 \mathrm{bp}$ fragment. The primer sequences for porcine HO-2 were designed according to the methods of Parfenova et al. (2001). The forward 5'-GGACA AYGCSCAGCAGTTCAAGCAG-3' and the reverse 5'-CGCAYRTCTCCTTTCCCATCGTG-3' primers were used to amplify a $213 \mathrm{bp}$ fragment. For the detection of porcine HO-1 and $\mathrm{HO}-2$ mRNA in PGCs, PCR amplification was carried out using a PCR core kit (Roche). Samples were amplified in a $50 \mu \mathrm{l}$ PCR solution
(10 mM Tris- $\mathrm{HCl} \mathrm{pH} 8 \cdot 3,50 \mathrm{mM} \mathrm{KCl,} 1.5 \mathrm{mM} \mathrm{MgCl}_{2}$, $0 \cdot 2 \mathrm{mM}$ dNTP, $2 \cdot 5$ IU Taq polymerase) with 30 cycles of the following sequential steps: denaturation at $94^{\circ} \mathrm{C}$ for $30 \mathrm{~s}$, annealing at $55^{\circ} \mathrm{C}$ for $60 \mathrm{~s}$, extension at $72{ }^{\circ} \mathrm{C}$ for $60 \mathrm{~s}$ in a Perkin-Elmer GeneAmp 2400 Thermal Cycler. The PCR products were subjected to $2 \cdot 0 \%$ agarose gel (Takara) electrophoresis and visualized by ethidium bromide staining. The sequences of the PCR produces were determined using an automated ABI Prism 310 sequencer (Perkin-Elmer Co.) and compared with those of HO-1 and HO-2 to confirm their identity. PCR amplification of samples without prior RT was performed as a negative control.

\section{Western blotting analysis of haem oxygenases and Fas ligand}

Porcine granulosa cells were obtained from different stages of follicles and cultured with haemin, a haem oxygenase substrate (Affiniti Research Product Ltd, Exeter, Devon, UK) or zinc protoporphyrin IX (ZnPP IX), a haem oxygenase inhibitor (Oxis, Portland, OR, USA), or both, for $24 \mathrm{~h}$. They were then lysed with lysis buffer $(50 \mathrm{mM}$ Tris- $\mathrm{HCl} \mathrm{pH} 7 \cdot 5,0 \cdot 15 \mathrm{M} \mathrm{NaCl}, 1 \%$ Nodidet P-40, 0·1\% deoxycholic acid, $10 \mu \mathrm{M}$ phenyl methylsulphonyl fluoride, $0.5 \mathrm{mU} / \mathrm{ml}$ apoprotinin, $1 \mu \mathrm{M}$ leupeptin, $1 \mu \mathrm{M}$ pepstatin) to analyse the expression of haem oxygenases and Fas ligand protein. Protein concentration was measured with a Micro BCA Protein Assay Reagent Kit (Pierce, Rockford, IL, USA) using BSA as the standard. Each sample contained equivalent amounts of protein (40 $\mu \mathrm{g}$ for experiments detecting expression of haem oxygenases and $15 \mu \mathrm{g}$ for experiments detecting Fas ligand), which were separated by $10 \%$ SDS-PAGE and transferred onto polyvinylidene difluoride membranes (Atto, Tokyo, Japan). After blocking with Block Ace (Dainippon, Osaka, Japan) containing 10\% FCS to prevent non-specific binding of the antibodies, the membranes were incubated with anti-HO-1 (1:1000) or anti-HO-2 (1:2000) polyclonal antibody (Stressgen), or with anti-Fasligand (1:1000) rabbit polyclonal antibody (Stressgen) for $1.5 \mathrm{~h}$ at room temperature. After a washing with buffer, the membranes were sequentially incubated with horseradish-peroxidase-conjugated anti-rabbit IgG antibody (1:5000) (Amersham). The bound antibodies were detected by enhanced chemiluminescence (Amersham) in accordance with the recommended procedure. Quantification was performed by computerized optimal densitometric scanning of images (National Institutes of Health image program), and then normalized using $\beta$-actin protein as an internal standard.

Immunocytochemical analysis of haem oxygenases and Fas ligand by flow cytometry

To detect the expression of haem oxygenases, PGCs obtained from different stages of follicles were dissociated 
enzymatically as described above. The cells were fixed in 4\% paraformaldehyde/D-PBS for $30 \mathrm{~min}$ at room temperature and then incubated with permeabilizing solution (5\% diethylene glycol and 1.5\% formaldehyde/D-PBS) (Becton Dickinson) for $10 \mathrm{~min}$ at room temperature. For analysis of Fas ligand, PGCs were cultured with different concentrations of two compounds, haemin and ZnPP IX, for $24 \mathrm{~h}$. All cells that remained adherent to the culture plates and PGCs that were floating in the culture medium were recovered and fixed in 4\% paraformaldehyde/D-PBS for $30 \mathrm{~min}$ at room temperature. After three washes with cold D-PBS, cells were preincubated for $30 \mathrm{~min}$ at $4{ }^{\circ} \mathrm{C}$ in D-PBS containing 5\% normal goat serum and 10\% FCS to prevent non-specific binding of antibodies for both haem oxygenases and Fas ligand. Cells were subsequently incubated with anti-HO-1 (1:50) or anti-HO-2 (1:50) polyclonal antibody (Stressgen) and anti-Fas-ligand (1:50) rabbit polyclonal antibody (Stressgen) for $30 \mathrm{~min}$ at $4{ }^{\circ} \mathrm{C}$. After two washes with cold D-PBS, the cells were incubated with fluorescein-isothiocyanate-conjugated anti-rabbit IgG (Southern Biotechnology Associate, Birmingham, AL, USA) for $30 \mathrm{~min}$ at $4{ }^{\circ} \mathrm{C}$. The cells were centrifuged, resuspended in $1.5 \mathrm{ml} 1 \%$ paraformaldehyde/D-PBS on ice, and analysed using a Beckton Dickinson FACS Calibur machine. At least 10000 events were recorded separately. Negative controls were prepared by replacing the primary antibody with an appropriately diluted normal rabbit serum and control rabbit IgG for haem oxygenases and Fas ligand, respectively.

Analysis of DNA contents in granulosa cells by flow cytometry

Porcine granulosa cells were seeded in $10 \mathrm{~cm}$ dishes and preincubated for $48 \mathrm{~h}$ at $37^{\circ} \mathrm{C}$ in a humidified $95 \%$ air $-5 \% \mathrm{CO}_{2}$ incubator. After preincubation, the medium was changed and the cells were incubated with haemin or ZnPP IX, or both, in serum-free phenol-red-free DMEM for different times $(4 \mathrm{~h}, 8 \mathrm{~h}, 16 \mathrm{~h}, 24 \mathrm{~h})$ and at different concentrations $(0 \cdot 1,1 \mu \mathrm{M})$. Floating cells and trypsinized cells, which were originally attached to the bottom of the culture dishes after each treatment, were collected and combined to ensure a complete recovery of the cell population. After washing with cold D-PBS, the cells were fixed in cold $70 \%$ ethanol, and then stored at $-20{ }^{\circ} \mathrm{C}$ until required for use (more than $4 \mathrm{~h}$ ). On the day of experiment, cells were centrifuged and supernatants were completely removed, and then cells were incubated in $200 \mu \mathrm{l}$ phosphate-citrate buffer $\left(0 \cdot 2 \mathrm{M} \mathrm{Na}_{2} \mathrm{HPO}_{4} 192 \mu \mathrm{l}\right.$ and $0 \cdot 1 \mathrm{M}$ citric acid $8 \mu \mathrm{l}$ ) at room temperature for $30 \mathrm{~min}$. After incubation, cells were stained for $30 \mathrm{~min}$ with $50 \mu \mathrm{g} / \mathrm{ml}$ propidium iodide (Molecular Probes, Engene, OR, USA) and $50 \mu \mathrm{g} / \mathrm{ml}$ ribonuclease A (Sigma)/D-PBS containing $0 \cdot 1 \%$ Triton-X (Sigma). Cells were filtered through a $35 \mu \mathrm{m}$ nylon mesh filter (Becton Dickinson) and then analysed by FACS. The percentage of sub-G1 phase (apoptotic) cells was calculated by CELL QUEST software. At least 30000 events were recorded in each specimen.

\section{Statistical analysis}

For immunohistochemical localization, sections from four independent porcine ovary samples were observed. All experiments were repeated at least three times to ensure reproducibility of the results, and the values were expressed as the means \pm S.D For comparison between unpaired groups, ANOVA was used. A $P$ value less than $0 \cdot 05$ was considered statistically significant.

\section{Results}

Determination of haem oxygenase localization by immunohistochemistry

Immunostaining for $\mathrm{HO}-1$ and $\mathrm{HO}-2$ was observed in all porcine ovaries studied; representative photomicrographs are shown in Figure 1. HO-1 protein was weakly expressed in PGCs in healthy follicles (Fig. 1A). In contrast, granulosa cells were stained intensely with the anti-HO-1 antibody in atretic follicles (Fig. 1B), in which large numbers of loose, pyknotic granulosa cells were found (Chaffin \& Stouffer 2000). Conversely, HO-2 protein was observed in granulosa cells in healthy follicles (Fig. 1C), whereas immunostaining for HO-2 was weak in granulosa cells in atretic follicles (Fig. 1D).

\section{Detection of haem oxygenases $m R N A$ by RT-PCR}

Polymerase chain reaction amplification of PGC cDNA with the HO-1 and $\mathrm{HO}-2$ primer sets generated the expected $331 \mathrm{bp}$ and $213 \mathrm{bp}$ fragments, respectively, from all PGC RNA samples (Fig. 2A, B), and the sequences of the products were identical to those of $\mathrm{HO}-1$ and $\mathrm{HO}-2$. Thus HO-1 and HO-2 mRNA was detected by RTPCR in PGCs at all stages of follicular development.

\section{Detection of haem oxygenase proteins by western blotting analysis}

Immunoreactivity against $\mathrm{HO}-1$ and $\mathrm{HO}-2$ proteins was detected in PGCs extracted from small, medium and large follicles, by western blotting. The HO-1 antibody produced a $32 \mathrm{kDa}$ protein band corresponding to the approximate molecular mass of porcine $\mathrm{HO}-1$ protein, and we detected $\mathrm{HO}-1$ in protein extracts from PGCs at all stages of follicular development (Fig. 2C). The HO-2 antibody produced a $36 \mathrm{kDa}$ protein band corresponding to the approximate molecular mass of porcine $\mathrm{HO}-2$ protein (Parfenova et al. 2001) and we also detected HO-2 

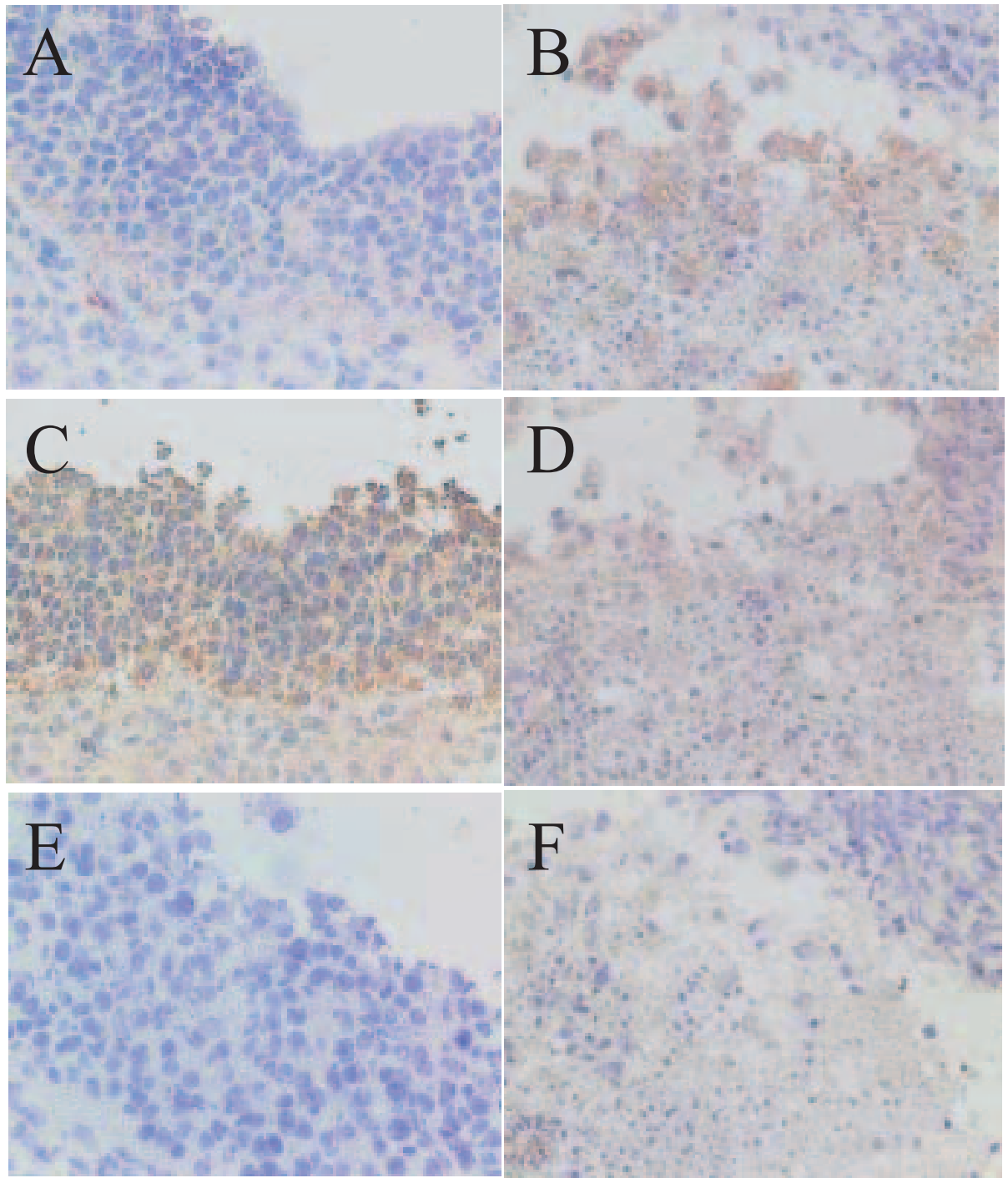

Figure 1 Immunohistochemical localization of haem oxygenase (HO)-1 and -2 proteins in the porcine ovary. (A) Stained with anti-HO-1 polyclonal antibody in the healthy follicle. (B) Stained with anti-HO-1 polyclonal antibody in the atretic follicle. (C) Stained with anti-HO-2 polyclonal antibody in the healthy follicle. (D) Stained with anti-HO-2 polyclonal antibody in the atretic follicle. (E)

Negative control (healthy follicle). (F) Negative control (atretic follicle). The immunostained sections were counterstained with Mayer's haematoxylin. Original magnification: $\times 400$.

in protein from PGCs at all stages of follicular development (Fig. 2D).

Determination of two subpopulations of PGCs by flow cytometry

A contour line analysis, forward scatter versus side scatter, was performed in whole PGCs and weakly associated PGCs. In the contour line of whole granulosa cells, containing both tightly bound and weakly associated PGCs, two peaks were identified (Fig. 3A). In contrast, in the contour line of weakly associated PGCs, only one peak was determined, which corresponded to the left peak of the previous picture (Fig. 3B). Therefore, we were able to set the gate (Fig. 3C) for the investigation of each subpopulation of PGCs, tightly bound or weakly associated, in subsequent experiments.

Detection of haem oxygenases in two subpopulations of PGCs by flow cytometric analysis

Two subpopulations of PGCs, tightly bound and weakly associated, were analysed separately by setting gates on the basis of the findings of the previous experiment. The 


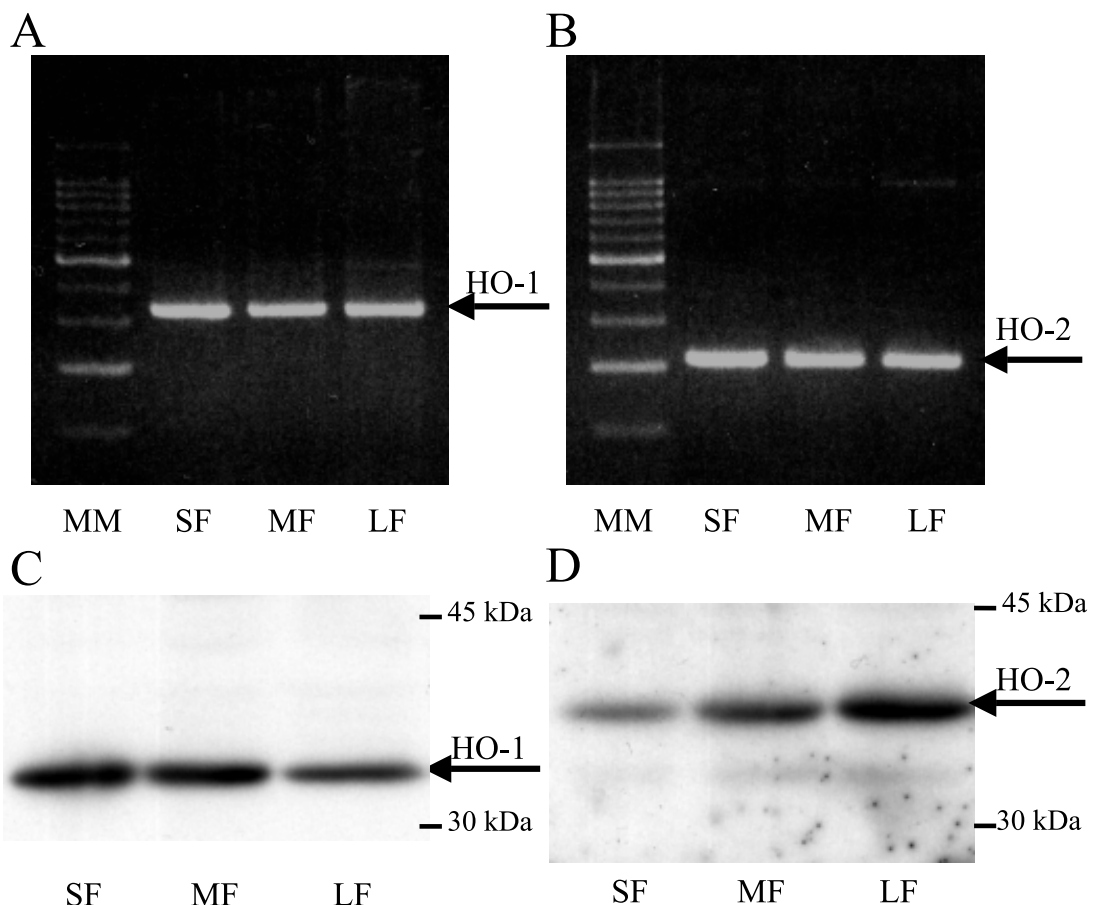

Figure 2 (A, B) RT-PCR analysis of expression of mRNA for haem oxygenase isozymes in porcine granulosa cells (PGCs) at each stage of follicular development. (A) HO-1 specific primers generated the expected $331 \mathrm{bp}$ fragment from all PGC RNA samples. (B) HO-2 specific primers generated the expected $213 \mathrm{bp}$ fragment from all PGC RNA samples. (C, D) Western blotting analysis of haem oxygenase isozymes using $\mathrm{HO}-1$ and HO-2 polyclonal antibodies against proteins extracted from PGCs in each stage of follicular development. (C) Anti-HO-1 antibody produced a protein band at $32 \mathrm{kDa}$ (approximate molecular mass of porcine HO-1). (D) Anti-HO-2 antibody produced a protein band at 36 kDa (approximate molecular mass of porcine HO-2). MM, 100 bp ladder marker; SF, small follicles ( $<2 \mathrm{~mm}$ ); MF, medium follicles (3-5 mm); LF, large follicles ( $>6 \mathrm{~mm}$ ).

histograms of the number of PGCs stained with $\mathrm{HO}-1$ antibody or normal rabbit serum (negative control) are shown in Figure 4A. Granulosa cells staining with HO-1 antibody had greater fluorescence intensity compared with negative controls, which is indicated in the histogram by a shift to the right. These results showed that HO-1 proteins were expressed in both tightly bound and weakly associated PGCs throughout follicular development. The histograms of PGCs stained with HO-2 antibody or normal rabbit serum (negative control) are shown in Figure 4B. HO-2 proteins were also expressed in both tightly bound and weakly associated PGCs throughout follicular development.

\section{Effect of haem oxygenase on granulosa cell apoptosis by a} sub-G1 phase population in DNA content analysis

We examined the effect of haemin on the number of PGCs using a WST-1 cell proliferation kit (Roche) before analysis for DNA content. The number of PGCs was significantly changed by treatment for $24 \mathrm{~h}$ with haemin in concentrations ranging from $0 \cdot 1 \mu \mathrm{M}$ to $1 \mu \mathrm{M}$, but was not altered by culture with less than $0.01 \mu \mathrm{M}$ of this agent (data not shown). Culture with haemin at $0 \cdot 1 \mu \mathrm{M}$ and $1 \mu \mathrm{M}$ was therefore considered to be suitable to examine the effect of haemin on granulosa cell apoptosis. We calculated the percentage of apoptotic PGCs treated with haemin to determine the effect of this compound on granulosa cell apoptosis. The two subpopulations of PGCs were analysed separately.

The effects of treatment of tightly bound PGCs with $1 \mu \mathrm{M}$ haemin at different times of culture are shown in Figure 5 . The apoptotic degradation of DNA induced by haemin treatment is shown in representative DNA histograms of tightly bound PGCs treated with or without $1 \mu \mathrm{M}$ haemin at different culture times (Fig. 5A). At the beginning of treatment $(0 \mathrm{~h})$, the proportion of sub-G1 phase PGCs, which contain subdiploid amounts of DNA, was low. The proportion of sub-G1 cells increased gradually and in a similar way in both haemin-treated and haemin-untreated cells for the first $16 \mathrm{~h}$, but the percentage of apoptotic cells was significantly greater at $24 \mathrm{~h}$ in haemin-treated cells. The results from three separate experiments are shown in Figure 5B. At the beginning of 

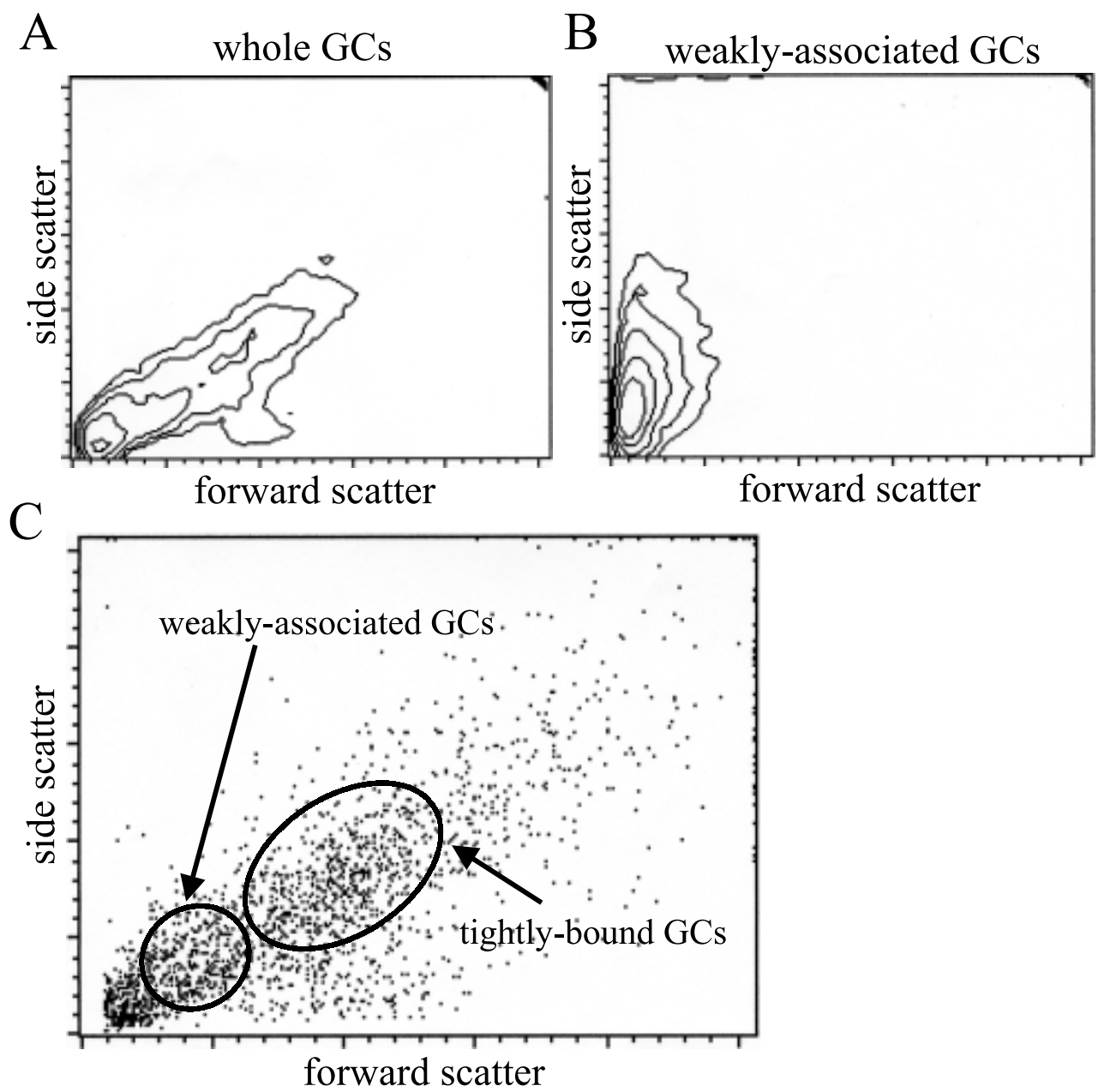

Figure 3 Two subpopulations of porcine granulosa cells (PGCs) separated by flow cytometry. (A) Contour line analysis in whole granulosa cells, containing tightly bound and weakly associated PGCs. (B) Contour line analysis in weakly associated PGCs, which were passed through the $0.8 \mu \mathrm{m}$ filter. (C) Setting gates of both tightly bound and weakly associated PGCs on the picture of dot plot analysis. We used the gate to investigate each subpopulation of PGCs in subsequent experiments.

treatment, the mean percentage of apoptotic cells was low $(0 \cdot 27 \pm 0 \cdot 17 \%$, mean \pm S.D. $)$, and reached approximately $10 \cdot 0 \%$ at $24 \mathrm{~h}$ of culture in untreated tightly bound PGCs. However, in tightly bound PGCs treated with $1 \mu \mathrm{M}$ haemin, the mean percentage of apoptotic cells continued to increase after $16 \mathrm{~h}$ of culture and was significantly increased compared with controls at $24 \mathrm{~h}$ of culture $(16 \cdot 5 \pm 3 \cdot 4 \%$ compared with $10 \cdot 0 \pm 2 \cdot 7 \%, P<0 \cdot 05)$.

Representative DNA histograms of weakly associated PGCs treated with or without $1 \mu \mathrm{M}$ haemin at different culture times are shown in Figure 6A. At the beginning of treatment $(0 \mathrm{~h})$, the proportion of sub-G1 phase GCs was low, but the percentage of apoptotic cells among haemintreated and haemin-untreated weakly associated PGCs increased dramatically over $24 \mathrm{~h}$ of culture time. The percentage of apoptotic weakly associated PGCs was not altered by treatment with $1 \mu \mathrm{M}$ haemin at any observed time point. The results from three separate cultures are shown in Figure 6B. The mean percentage of apoptotic cells was low at $0 \mathrm{~h}(6 \cdot 0 \pm 3 \cdot 1 \%)$, and was significantly increased at $4 \mathrm{~h}$ of culture in serum-free conditions $(50 \cdot 0 \pm 6 \cdot 8 \%)$. The percentage of apoptotic cells in weakly associated PGCs in untreated control culture continued to increase and reached approximately $90 \cdot 0 \%$ at $24 \mathrm{~h}$ culture. In weakly associated PGCs treated with $1 \mu \mathrm{M}$ haemin, the mean percentage of apoptotic cells increased in a manner similar to that in control cultures.

To confirm the effect of haemin on apoptosis in tightly bound PGCs and the inhibitory effect of ZnPP IX on haemin-induced apoptosis, we cultured the cells with haemin or haemin and ZnPP IX at different concentrations for $24 \mathrm{~h}$. Representative DNA histograms of 
A
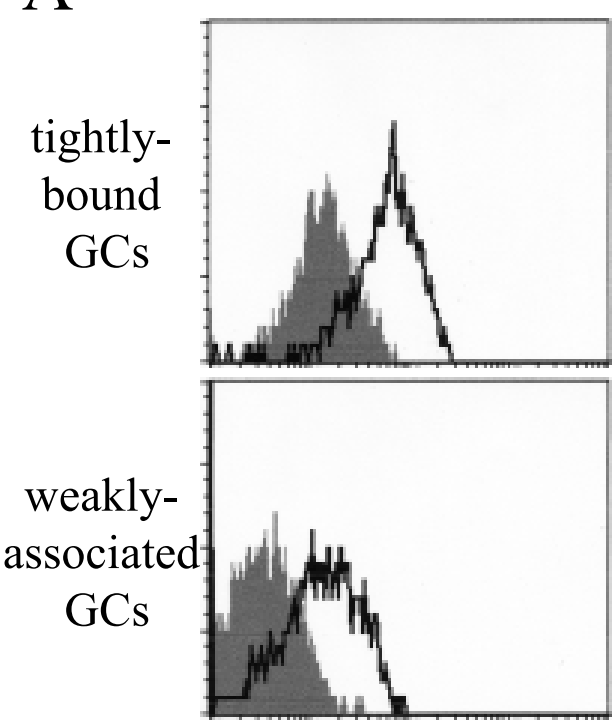

small follicles

$(<2 \mathrm{~mm})$

B

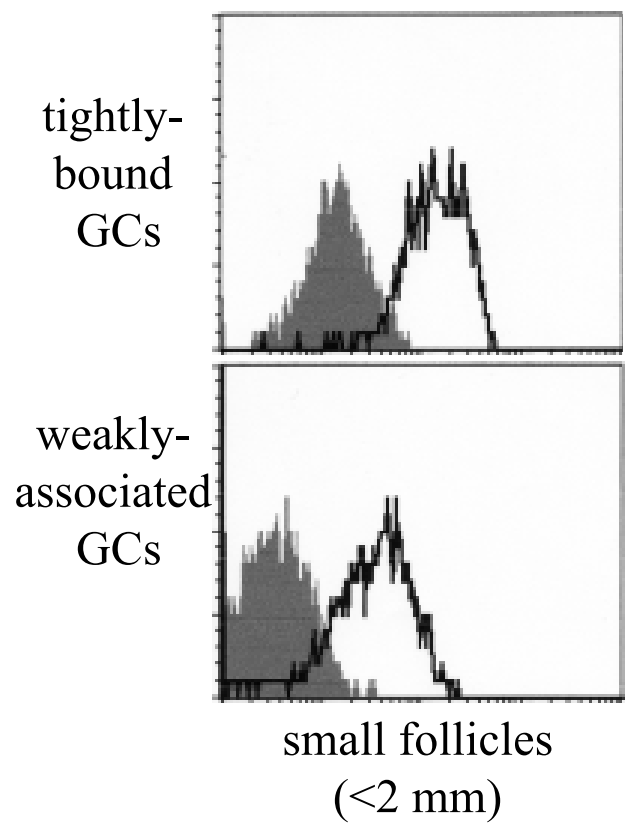

HO-1
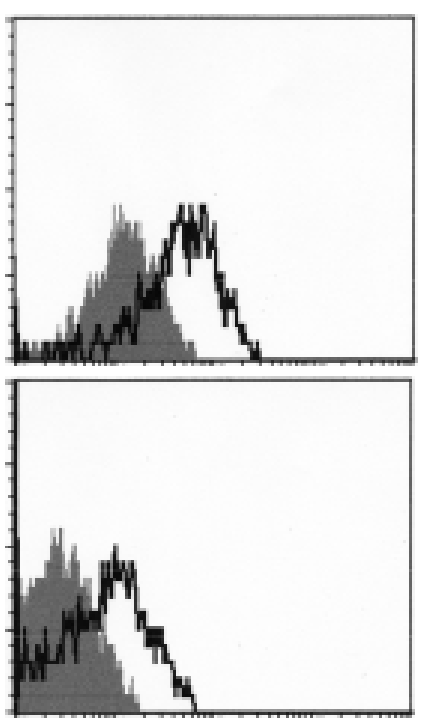

medium follicles

(3-5 mm)

HO-2
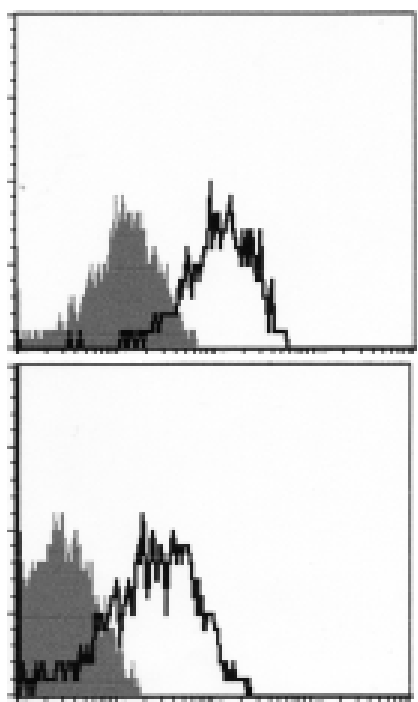

medium follicles

(3-5 mm)
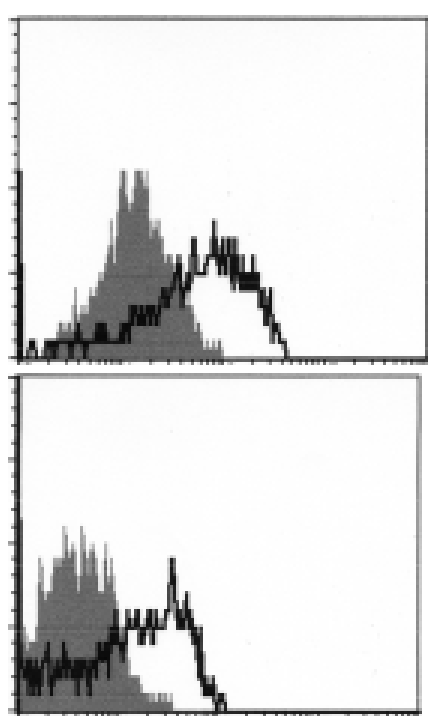

large follicles

(>6 mm)
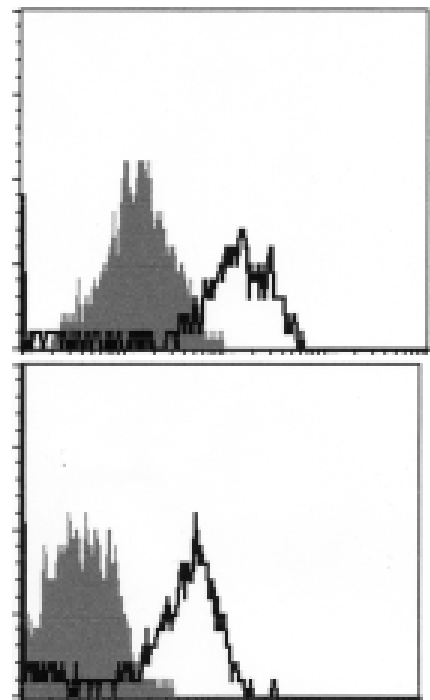

large follicles

(>6 mm)

Figure 4 (A) Immunocytochemistry analysis of HO-1 expression in porcine granulosa cells (PGCs) by flow cytometry. PGCs staining with HO-1 antibody had greater fluorescence intensity than negative controls, so the histogram of cells staining with HO-1 antibody was shifted to the right. These results indicate that HO-1 proteins were expressed in both tightly bound and weakly associated PGCs throughout follicular development. (B) Immunocytochemistry analysis of HO-2 expression in PGCs using flow cytometry. These results show that $\mathrm{HO}-2$ proteins were expressed in both tightly bound and weakly associated PGCs throughout follicular development. 
A

Oh

4h

$8 \mathrm{~h}$

$16 \mathrm{~h}$

$24 \mathrm{~h}$
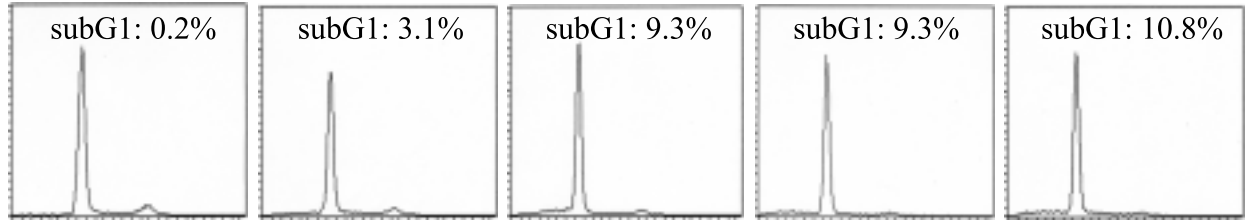

control
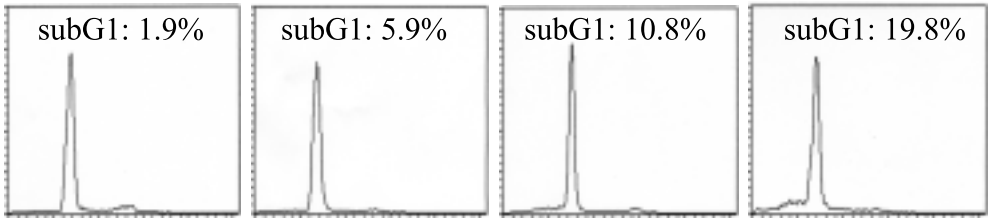

\section{haemin $1 \mu \mathrm{M}$}

B

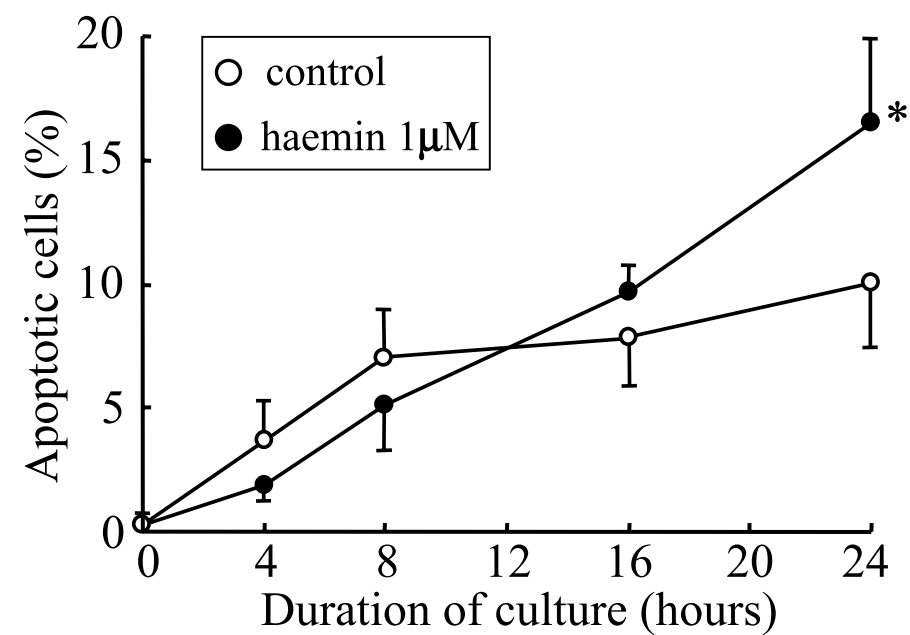

Figure 5 Effect of culture time and haemin, a haem oxygenase substrate, on apoptosis in tightly bound porcine granulosa cells (PGCs). (A) Representative DNA histograms in tightly bound PGCs treated with or without haemin at different culture times. (B) Mean percentage of apoptotic cells at different culture times in tightly bound PGCs. $\bigcirc$, Control (serum starvation only); $\bullet$, treated with haemin $1 \mu \mathrm{M}$. Data are means \pm S.D. of three independent experiments. ${ }^{*} P<0.05$ compared with control at the same culture time.

tightly bound PGCs are shown in Figure 7A. The proportion of sub-G1 phase cells in tightly bound PGCs was significantly increased by treatment with $1 \mu \mathrm{M}$ haemin compared with control culture. The proportion of sub-G1 phase cells in tightly bound PGCs treated with $0 \cdot 1$ or $1 \mu \mathrm{M} \mathrm{ZnPP}$ IX in the presence of $1 \mu \mathrm{M}$ haemin was decreased compared with cultures treated with $1 \mu \mathrm{M}$ haemin. The results of four separate experiments in tightly bound PGCs are summarized in Figure 7B. The mean percentage of apoptotic cells was significantly increased by treatment with haemin: the rate of apoptosis among cells treated with $1 \mu \mathrm{M}$ haemin was approximately $1 \cdot 7$-fold increased compared with that in untreated control cultures $(17 \cdot 2 \pm 1 \cdot 9 \%$ compared with $9 \cdot 8 \pm 1 \cdot 9 \%, \quad P<0 \cdot 05)$. Furthermore, compared with that in haemin-treated cultures, the mean percentage of apoptotic cells was significantly and dose-dependently decreased by treatment with $\mathrm{ZnPP}$ IX in the presence of $1 \mu \mathrm{M}$ haemin.

Effect of haem oxygenase on Fas ligand by quantitative analysis of western blotting

To investigate the correlation between haemin-induced apoptosis and expression of Fas ligand, we sought to determine the expression of Fas ligand in PGCs treated with haemin, using western blotting. The Fas ligand antibody produced a $38 \mathrm{kDa}$ protein band identical to the approximate molecular mass of porcine Fas ligand protein. The quantity of Fas ligand protein was significantly increased $(P<0.05)$ by treatment with haemin, in a dose-dependent manner (Fig. 8A). The results of the densitometric analysis are shown in Figure 8B. The 

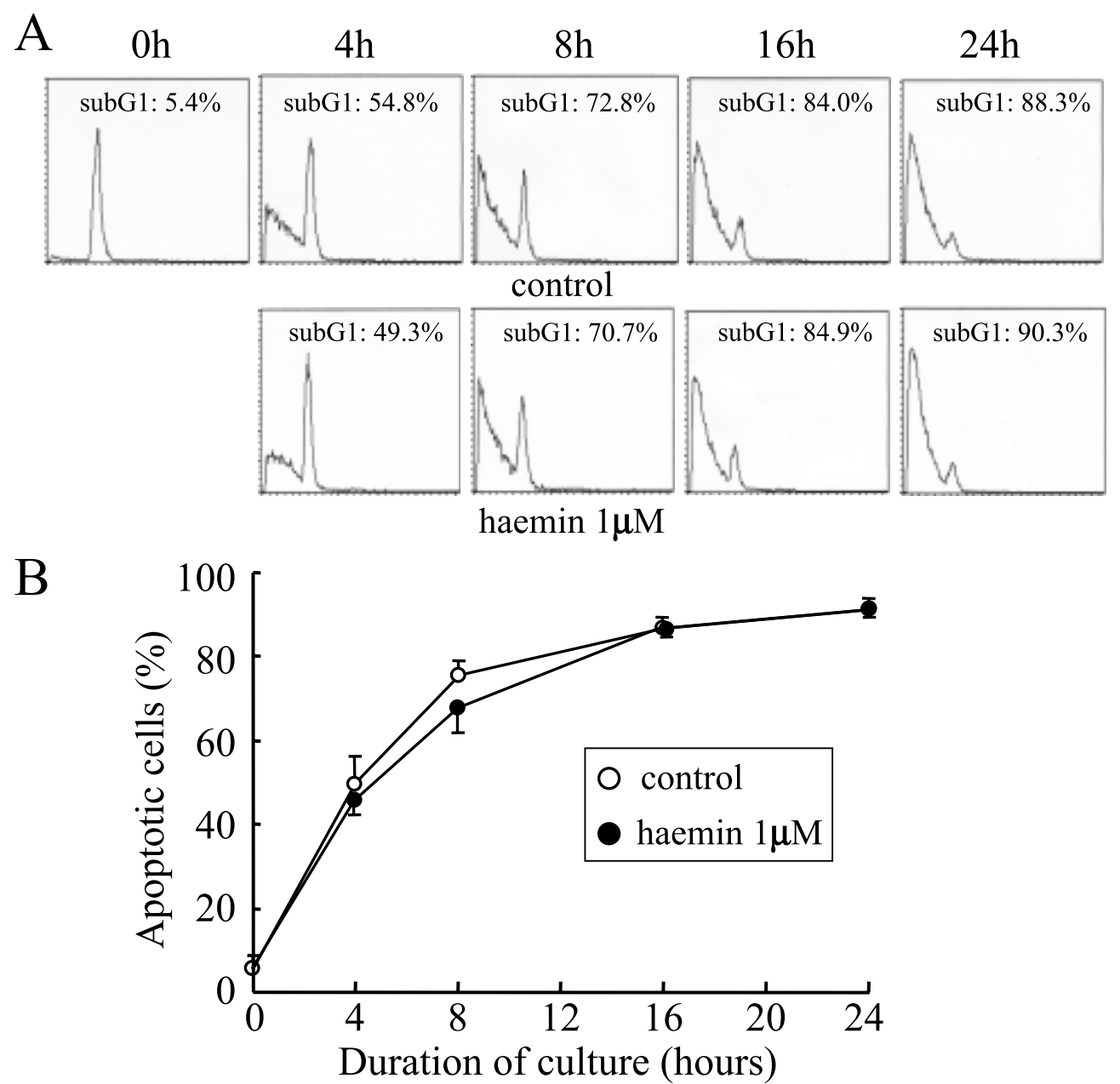

Figure 6 Effect of culture time and haemin, a haem oxygenase substrate, on apoptosis in weakly associated porcine granulosa cells (PGCs). (A) Representative DNA histograms in weakly associated PGCs treated with or without haemin at different culture times. (B) Mean percentage of apoptotic cells at different culture times in weakly associated PGCs. $\bigcirc$, Control (serum starvation only); $\mathbf{0}$, treated with haemin $1 \mu \mathrm{M}$. Data are means \pm S.D. of three independent experiments.

quantity of Fas ligand protein from PGCs treated with $1 \mu \mathrm{M}$ haemin was approximately $1 \cdot 5$-fold increased compared with the control.

Effect of haem oxygenases on Fas ligand in tightly bound PGCs by flow cytometric analysis

To determine whether Fas ligand was induced by haemin and whether this effect was inhibited by ZnPP IX in tightly bound PGCs, we examined the expression of Fas ligand protein by flow cytometry. Representative histograms of the number of tightly bound PGCs staining with anti-Fas-ligand antibody are shown in Figure 9. PGCs stained with anti-Fas-ligand antibody had greater fluorescence intensity than negative controls (grey area), indi- cating that Fas ligand protein was expressed in tightly bound PGCs at $24 \mathrm{~h}$ of culture. PGCs staining with anti-Fas-ligand antibody demonstrated greater fluorescence intensity when treated with haemin, compared with untreated controls (Fig. 9A). The inhibitory effect of ZnPP IX on the haemin-induced increase in Fas ligand protein in tightly bound PGCs was also investigated. Fluorescence intensity in PGCs staining with anti-Fasligand antibody was decreased by treatment with ZnPP IX in the presence of haemin, indicating that the increase in Fas ligand produced by haemin was inhibited by ZnPP IX (Fig. 9B).

We calculated the relative amount of fluorescence intensity in each treatment group compared with the control. The results from three separate experiments are 


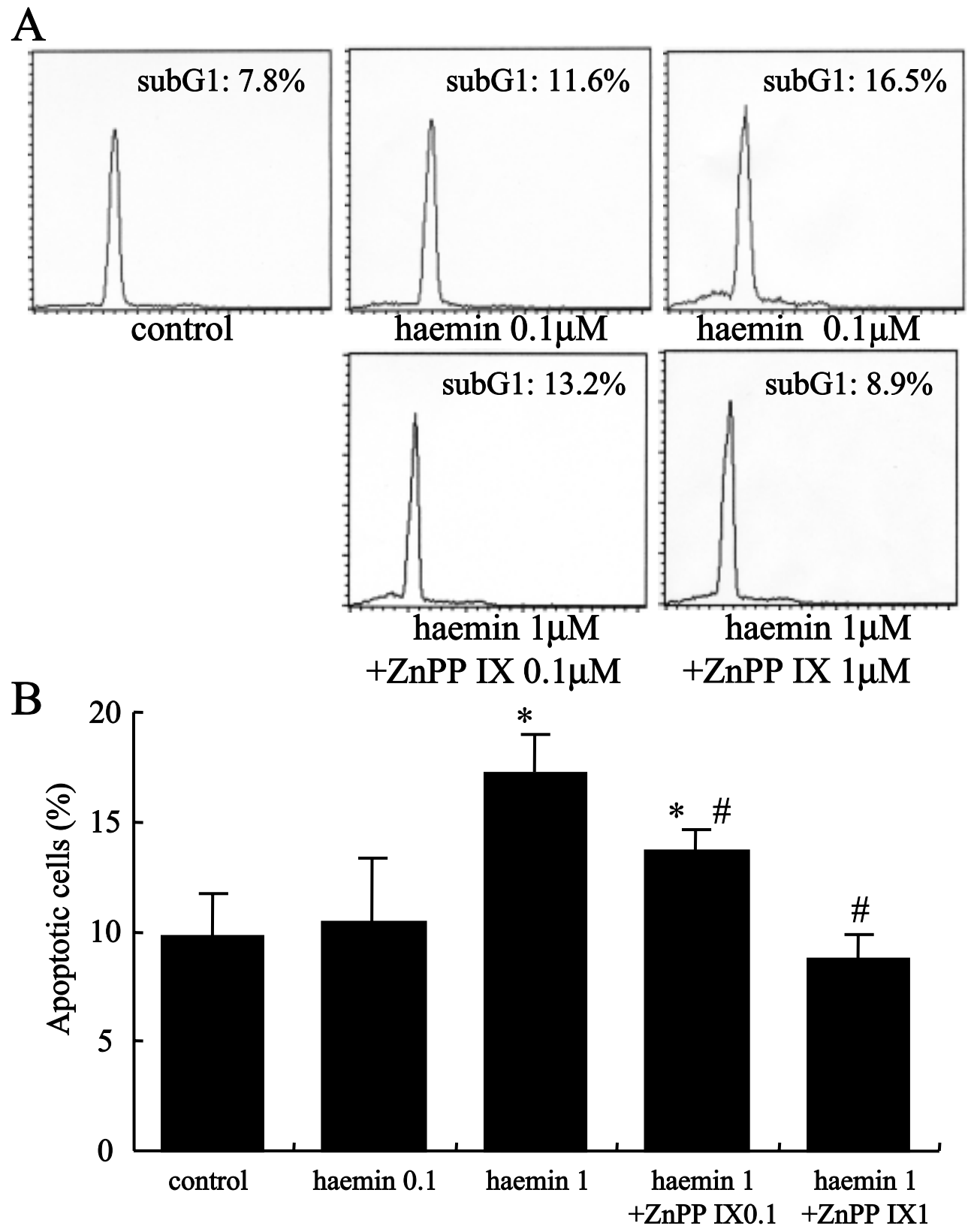

Figure 7 Effect of haem oxygenases on apoptosis in tightly bound porcine granulosa cells (PGCs).

(A) Representative DNA histograms in tightly bound PGCs treated with haemin (haem oxygenase substrate) or both haemin and zinc protoporphyrin IX (ZnPP IX; haemoxygenase inhibitor), at $24 \mathrm{~h}$ of culture. (B) Mean percentage of apoptotic cells treated with different concentration of haemin or ZnPP IX, or both. The proportion of apoptotic cells was significantly increased by haemin $1 \mu \mathrm{M}$ compared with control in tightly bound PGCs, and haemin-induced apoptosis was completely inhibited by ZnPP IX $1 \mu \mathrm{M}$. Data are means \pm S.D. of four independent experiments. $P<0.05$ compared with: ${ }^{*}$ control, ${ }^{\#}$ treatment with haemin $1 \mu \mathrm{M}$.

summarized in Figure 9C. The mean fluorescence intensity was increased by haemin compared with control in tightly bound PGCs, and ZnPP IX inhibited the haemin- induced increase in a dose-dependent manner. These results suggest that haem oxygenase might regulate the expression of Fas ligand protein in tightly bound PGCs. 


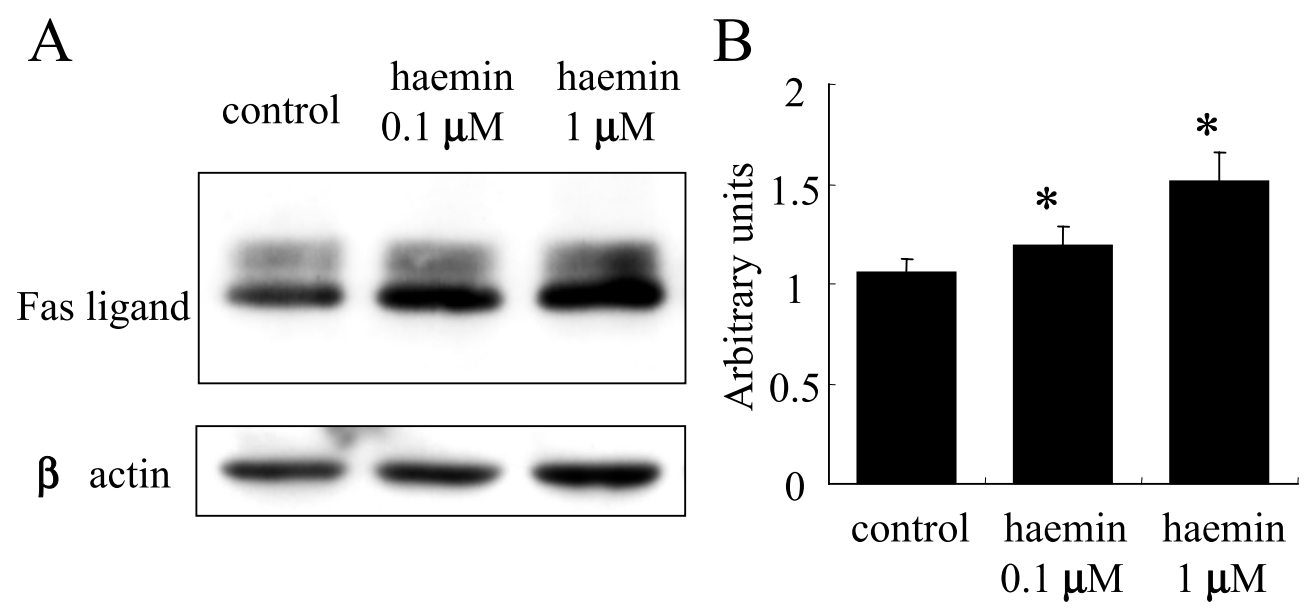

Figure 8 Effect of haemin on Fas ligand expression in porcine granulosa cells (PGCs). (A) Western blotting analysis of Fas ligand using polyclonal antibody against proteins extracted from PGCs treated with haemin. Anti-Fas-ligand antibody reacted with a protein band of $38 \mathrm{kDa}$ (approximate molecular mass of porcine Fas ligand). (B) Densitometric analysis of Fas ligand protein in PGCs treated with haemin. Bars represent arbitrary units and are shown as the means \pm S.D. of three independent experiments. ${ }^{\star} P<0 \cdot 05$ compared with control.

\section{Discussion}

This study demonstrated that two haem oxygenase isozymes, inducible $\mathrm{HO}-1$ and constitutive $\mathrm{HO}-2$, are expressed in granulosa cells in the porcine ovary; HO-1 protein was mainly present in granulosa cells in the atretic follicle, whereas $\mathrm{HO}-2$ protein was constitutively observed in granulosa cells in the healthy follicle. Furthermore, this study demonstrated, for the first time, the detection of both haem oxygenase isozymes in freshly isolated PGCs during follicular development by RT-PCR and western blotting, and the presence of both isozymes in the two subpopulations of PGCs (tightly bound and weakly associated GCs) that were freshly isolated (Fig. 4) and cultured (data not shown), by flow cytometric analysis.

Porcine granulosa cells consist of two subpopulations, tightly bound and weakly associated (Howard \& Ford 1994). Tightly bound PGCs originate from the mural layers that border the basement membrane of the follicles, whereas weakly associated PGCs originate from the antral layers (Howard \& Ford 1994). We were able to characterize two subpopulations of PGCs by flow cytometry and dot plot analysis, comparing forward scatter and side scatter, in both freshly isolated and cultured PGCs. We found that there was a different apoptotic response to serum starvation in tightly bound and weakly associated PGCs. After $48 \mathrm{~h}$ of preincubation in medium containing $10 \%$ FCS, the proportion of apoptotic cells was less than $1 \%$ in tightly bound PGCs and approximately $6 \%$ in weakly associated PGCs. The proportion of apoptotic cells in tightly bound PGCs increased to approximately 10\% at $24 \mathrm{~h}$ under serum starvation. However, in weakly associated PGCs, the proportion of apoptotic cells dramatically increased to approximately $90 \%$ at $24 \mathrm{~h}$ under the same conditions. The two subpopulations of PGCs have different characteristics regarding steroid production, mitotic potential and protein content (Marrone \& Crissman 1988, Howard \& Ford 1994, Duda et al. 1999); this is the first report of different apoptotic responses to serum starvation between the two subpopulations of PGCs.

We determined that the rate of apoptosis was significantly increased in tightly bound PGCs by treatment with haemin, and that ZnPP IX, a haem oxygenase inhibitor, inhibited haemin-induced apoptosis. However, the proportion of apoptotic cells was not altered by treatment with haemin in weakly associated PGCs. Because haemin and ZnPP IX were used previously as, respectively, a haem oxygenase substrate and a haem oxygenase inhibitor, to investigate the effect of haem oxygenase on various phenomena in many organs (Eyssen-Hernandez et al. 1996, Ye \& Laychock 1998, Duckers et al. 2001, Alexandreanu \& Lawson 2003), we used both compounds in this study. Although high concentrations of ZnPP IX decrease both haem oxygenase and NOS activities, it had been reported previously that, in concentrations lower than $1 \mu \mathrm{M}$, it was able to inhibit haem oxygenase activity but did not affect NOS activity (Appleton et al. 1999). At the range of concentration used in this study, ZnPP IX was thus considered to be specific for haem oxygenase. On the basis of these findings, we speculate that products catalysed by haem oxygenase may be apoptotic factors in tightly bound PGCs.

Haem oxygenases are present in a number of cells and tissues, and $\mathrm{CO}$, iron and bilirubin, which are formed from the haem ring by these enzymes, are recognized as apoptotic or antiapoptotic molecules in several systems. 
A

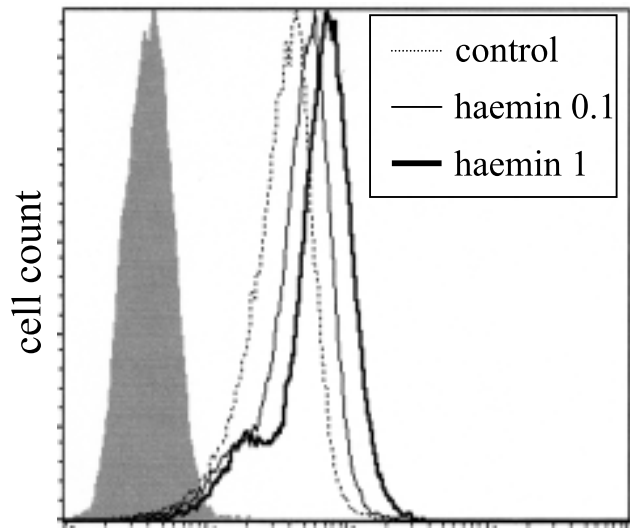

Fas ligand FITC
B

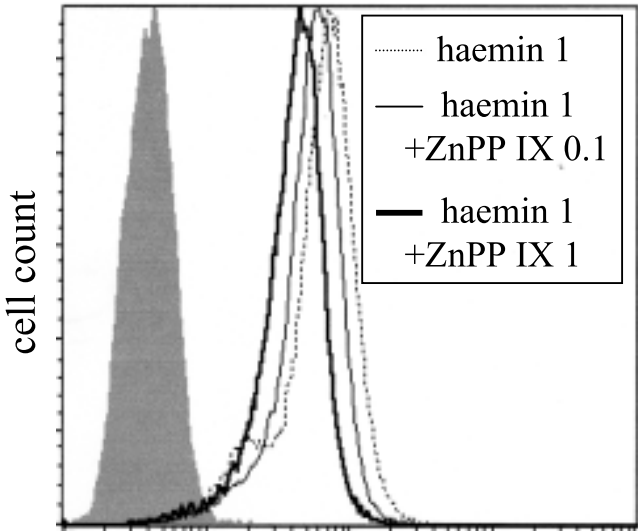

Fas ligand FITC

$\mathrm{C}$

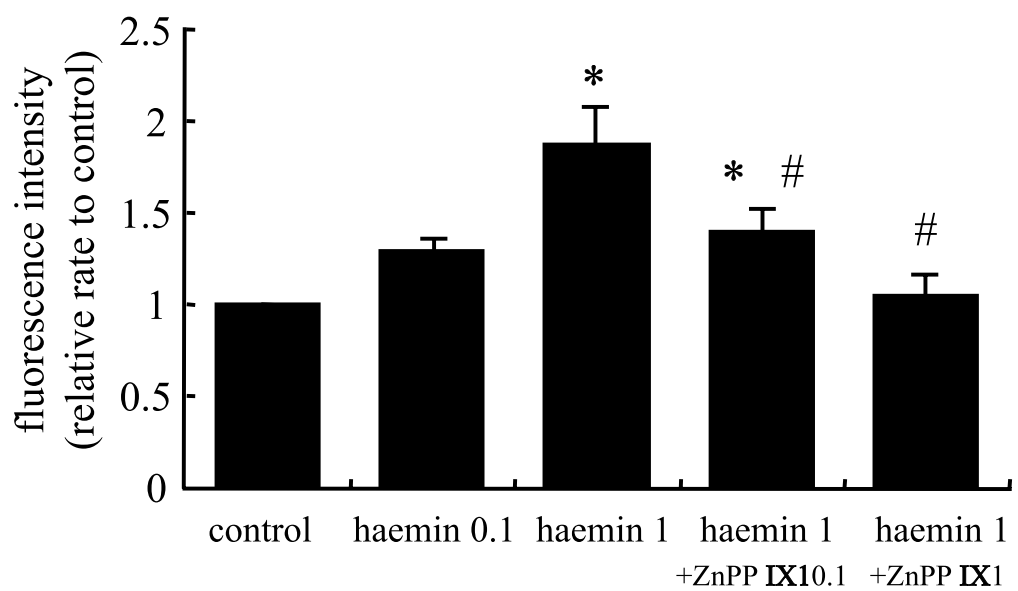

Figure 9 (A) Representative histograms of cells staining with anti-Fas-ligand antibody in tightly bound porcine granulosa cells (PGCs) treated or not treated with haemin. PGCs staining with anti-Fas-ligand antibody had greater fluorescence intensity after treatment with haemin compared with control. (B) Representative histograms of cells staining with anti-Fas-ligand antibody in tightly bound PGCs treated or not treated with ZnPP IX in the presence of haemin. PGCs staining with anti-Fas-ligand antibody had less fluorescence intensity after treatment with ZnPP IX compared with cultures treated with $1 \mu \mathrm{M}$ haemin. (C) Mean fluorescence intensity in PGCs treated with haemin or both haemin and ZnPPIX (relative to control). The fluorescence intensity was increased by haemin compared with control in tightly bound PGCs, and ZnPP IX inhibited the increase induced by haemin in a dose-dependent manner. Bars represent the means \pm S.D. of three independent experiments. $P<0.05$ compared with: ${ }^{*}$ control, ${ }^{*}$ treatment with haemin $1 \mu \mathrm{M}$.

In a murine endothelial cell line, $\mathrm{CO}$ generated by $\mathrm{HO}-1$ acts as an antiapoptotic molecule that can suppress cell apoptosis by activation of p38 MAPK (Brouard et al. 2000). In murine fibroblasts, HO-1 shows a protective role against cell apoptosis induced by serum deprivation, by reducing intracellular iron concentrations (Ferris et al. 1999). Furthermore, in rat cultured pancreatic islets, haem oxygenase provides a protective role against the actions of IL- $\beta$-induced NO, which induces cell apoptosis and inhibits insulin release (Ye \& Laychock 1998). Conversely, adenovirus-mediated transfer of HO-1 stimulates apoptosis in rat vascular smooth muscle cells through bilirubin, a product of the catalysis of haem by haem oxygenase (Liu et al. 2000). In the male reproductive organ, HO-1 protein was present in a low concentration in normal testes, but cadmium chloride increased HO-1 activity in Leydig cells, to cause germ cell apoptosis by CO (Ozawa et al. 2002). Thus bilirubin is an apoptotic factor in vascular smooth muscle cells and CO induces apoptosis in germ cells in testis, respectively. Although we showed that haem oxygenase products augmented granulosa cell apoptosis, further experiments are needed to determine which factor produced by haem oxygenase stimulates this apoptosis in porcine ovary.

We demonstrated that Fas ligand was significantly increased by haemin and decreased by ZnPP IX in PGCs, 
which suggests that haem oxygenase has the ability to upregulate Fas ligand protein in tightly bound PGCs. Follicular atresia and luteolysis are generally considered to occur by apoptosis. Recent reports characterizing the molecular mechanisms underlying this process demonstrate the role of several factors, including intracellular calcium concentration, MAPK, adenosine triphosphatase and extracellular-signal regulated kinase (Gebauer et al. 1999, Peluso et al. 2001, 2003, Park et al. 2003). The Fas/Fas ligand system has been identified as a mediator of granulosa cell apoptosis in the rat ovary (Hakuno et al. 1996, Kim et al. 1999), and treatment with monoclonal anti-human-Fas antibody induces apoptosis in cultured human granulosa/luteal cells (Quirk et al. 1995). Fasmediated cell-death pathways are considered to be central to the induction of follicular atresia (Quirk et al. 1995, 2000, Hakuno et al. 1996, Kim et al. 1999). Our data demonstrate that haem oxygenase has the ability to increase the production of Fas ligand protein, after granulosa cell apoptosis, in tightly bound PGCs, which suggests that products generated by haem oxygenase may be autocrine/paracrine factors that promote granulosa cell apoptosis.

Haem oxygenases are induced by various factors (Otterbein \& Choi 2000). Several authors have shown that HO-1 was induced by heat shock, heavy metals, hypoxia and endotoxin (Eyssen-Hernandez et al. 1996, Carraway et al. 1998, Panchenko et al. 2000, Stuhlmeier 2000). Furthermore, HO-1 was induced by TNF- $\alpha$ (Terry et al. 1998), which is known to stimulate granulosa cell apoptosis (Kaipai et al. 1996). In porcine granulosa cells, we have demonstrated that $\mathrm{HO}-1$ was mainly expressed in granulosa cells in the atretic follicle, and was present in freshly isolated and cultured granulosa cells, but we have not studied the nature of the factors that induced HO-1. HO- 1 may be induced by stress factors, and may play a part in controlling the female gamete in stressful environments through granulosa cell apoptosis in the ovaries, as occurs in testes (Ozawa et al. 2002). Further investigation of the regulatory mechanisms of the expression of haem oxygenase and the possible role of haem oxygenase in atresia is warranted.

In conclusion, the present study demonstrates that two haem oxygenase isozymes, inducible HO-1 and constitutive $\mathrm{HO}-2$, can be identified in both subpopulations of granulosa cells - tightly bound and weakly associated throughout follicular development, and that $\mathrm{HO}-1$ was strongly expressed in granulosa cells in the atretic follicles. A product of the catalysis of haem by haem oxygenase augments apoptosis in tightly bound PGCs (which originate from the mural layers that border the basement membrane of the follicles), possibly by upregulation of the Fas ligand protein. Although further studies are needed to prove the direct relationship between haem oxygenases and follicular atresia, the products produced by haem oxygenase, namely $\mathrm{CO}$, bilirubin and ferritin, can be considered to be autocrine/paracrine factors of apoptosis in PGCs, and may be important factors in atresia.

\section{Acknowledgements}

We acknowledge Samuel Parry for his critical review of this manuscript. This study was supported by Science Grants to T Kubota (14571544) and H Koi (12671582) from the Ministry of Education, Culture, Sports, Science and Technology of Japan.

\section{References}

Alexandreanu IC \& Lawson DM 2003 Heme oxygenase in the rat ovary: immunohistochemical localization and possible role in steroidogenesis. Experimental Biology and Medicine 228 59-63.

Appleton SD, Chretien ML, Mclaughlin BE, Vreman HJ, Stevenson DK, Brien JF, Nakatsu K, Maurice DH \& Marks GS 1999 Selective inhibition of heme oxygenase, without inhibition of nitric oxide synthase or soluble guanylyl cyclase, by metalloporphyrins at low concentrations. Drug Metabolism and Disposition 27 1214-1219.

Billig H, Furuta I \& Hsueh AJW 1993 Gonadotropin-releasing hormone directly induces apoptosis cell death in the rat ovary: biochemical and in situ detection of deoxyribonucleic acid fragmentation in granulosa cells. Endocrinology 134 245-252.

Brouard S, Otterbein LE, Anrather J, Tobiasch E, Bach FH, Choi AMK \& Soares MP 2000 Carbon monoxide generated by heme oxygenase 1 suppresses endothelial cell apoptosis. Journal of Experimental Medicine 192 1015-1025.

Carraway MS, Ghio AJ, Taylor JL \& Piantadosi CA 1998 Induction of ferritin and heme oxygenase- 1 by endotoxin in the lung. American Journal of Physiology. Lung Cellular and Molecular Physiology 275 L583-L592.

Chaffin CL \& Stouffer RL 2000 Role of gonadotrophins and progesterone in the regulation of morphological remodeling and atresia in the monkey peri-ovulatory follicle. Human Reproduction 15 2489-2495.

Chun SY, Eisenhauer KM, Kubo M \& Hsueh AJW 1995 Interleukin-1 $\beta$ suppresses apoptosis in rat ovarian follicles by increasing nitric oxide production. Endocrinology 136 3120-3127.

Costa A, Poma A, Navarra P, Forsling ML \& Grossman A 1996 Gaseous transmitters as new agents in neuroendocrinology regulation. Journal of Endocrinology 149 199-207.

Duckers HJ, Boehm M, True AL, Yet S-F, San H, Park JL, Webb RC, Lee M-E, Nabel GJ \& Nabel EG 2001 Heme oxygenase-1 protects against vascular constriction and proliferation. Nature Medicine 7 693-698.

Duda M, Gasińska A \& Gregoraszczuk EL 1999 Flow cytometric cell cycle analysis of two subpopulations of porcine granulosa cells. Experimental and Clinical Endocrinology and Diabetes 107 203-207.

Eyssen-Hernandez R, Ladoux A \& Frelin C 1996 Differential regulation of cardiac heme oxygenase-1 and vascular endothelial growth factor mRNA expression by hemin, heavy metals, heat shock and anoxia. FEBS Letters 382 229-233.

Ferris CD, Jaffrey SR, Sawa A, Takahashi M, Brady SD, Barrow RK, Tysoe SA, Wolosker H, Barañano DE, Synder SH et al. 1999 Haem oxygenase-1 prevents cell death by regulating cellular iron. Nature Cell Biology 1 152-157.

Gebauer G, Peter AT, Onesime D \& Dhanasekaran N 1999 Apoptosis of ovarian granulosa cells: correlation with the reduced activity of ERK-signaling module. Journal of Cellular Biochemistry 75 547-554. 
Gorospe WC, Hughes FM Jr \& Spangelo BL 1992 Interleukin-6: effects on and production by rat granulosa cells in vitro. Endocrinology 130 1750-1752.

Hakuno N, Koji T, Yano T, Kobayashi N, Tsutsumi O, Taketani Y \& Nakane PK 1996 Fas/APO-1/CD95 system as a mediator of granulosa cell apoptosis in ovarian follicle atresia. Endocrinology 137 1938-1948.

Harada T, Kubota T \& Aso T 2002 Usefulness of CA19-9 versus CA125 for the diagnosis of endometriosis. Fertility and Sterility $\mathbf{7 8}$ 733-739.

Howard HJ \& Ford JJ 1994 Differential steroidogenic response of subpopulation of porcine granulosa cells to insulin-like growth factor-1 (IGF-1) or IGF-1 analogs. Biology of Reproduction $\mathbf{5 1}$ $108-115$.

Hsu SY, Lai RJ-M, Finegold M \& Hsueh AJW 1996 Targeted overexpression of $\mathrm{Bcl}-2$ in ovaries of transgenic mice leads to decreased follicle apoptosis, enhanced folliculogenesis, and increased germ cell tumorigenesis. Endocrinology 137 4837-4843.

Kaipai A \& Hsueh AJW 1997 Regulation of ovarian follicle atresia. Annual Review of Physiology 59 349-363.

Kaipai A, Chun S-Y, Eisenhauer K \& Hsueh AJW 1996 Tumor necrosis factor- $\alpha$ and its second messenger, ceramide, stimulate apoptosis in cultured ovarian follicles. Endocrinology 137 4864-4870.

Kim CK \& Rivier CL 2000 Nitric oxide and carbon monoxide have a stimulatory role in the hypothalamic-pituitary-adrenal response to physio-emotional stressors in rats. Endocrinology $1412244-2253$.

Kim JM, Yoon YD \& Tsang BK 1999 Involvement of the Fas/Fas ligand system in p53-mediated granulosa cell apoptosis during follicular development and atresia. Endocrinology 140 2307-2317.

Leffler CW, Nasjletti A, Yu C, Johnson RA, Fedinec AL \& Walker N 1999 Carbon monoxide and cerebral microvascular tone in newborn pig. American Journal of Physiology. Heart and Circulatory Physiology $45 \mathrm{H} 1641-\mathrm{H} 1646$.

Liu X-M, Chapman GB, Wang H \& Durante W 2000 Adenovirus-mediated heme oxygenase-1 gene expression stimulates apoptosis in vascular smooth muscle cells. Circulation 105 79-84.

McCoubrey WK Jr, Ewing JF \& Maines MD 1992 Human heme oxygenase-2: characterization and expression of a full-length cDNA and evidence suggesting that the two HO-2 transcripts may differ by choice of polyadenylation signal. Archives of Biochemistry and Biophysics 295 13-20.

McCoubrey WK Jr, Huang TJ \& Maines MD 1997 Isolation and characterization of cDNA from the rat brain that encodes hemoprotein heme oxygenase-3. European Journal of Biochemstry 247 725-732.

Maines MD 1988 Heme oxygenase: function, multiplicity, regulatory, mechanisms, and clinical applications. FASEB Journal 2 2557-2568.

Maines MD \& Trakshel GM 1992 Tin-protoporphyrin: a potent inhibitor of hemoprotein-dependent steroidogenesis in rat adrenals and testes. Journal of Pharmacology and Experimental Therapeutics 260 909-916.

Marrone BL \& Crissman HA 1988 Characterization of granulosa cell subpopulations from avian preovulatory follicles by multiparameter flow cytometry. Endocrinology 122 651-658.

Masuda M, Kubota T, Kamada S \& Aso T 1997 Nitric oxide inhibits steroidogenesis in culutured porcine granulosa cells. Molecular Human Reproduction 3 285-292.

Otterbein LE \& Choi AMK 2000 Heme oxygenase: colors of defense against cellular stress. American Journal of Physiology. Lung Cellular and Molecular Physiology 279 L1029-1037.

Ozawa N, Goda N, Makino N, Yamaguchi T, Yoshimura Y \& Suematsu M 2002 Leydig cell-derived heme oxygenase-1 regulates apoptosis of premeiotic germ cells in response to stress. Journal of Clinical Investigation 109 457-467.

Panchenko MV, Farber HW \& Korn JH 2000 Induction of heme oxygenase- 1 by hypoxia and free radicals in human dermal fibroblasts. American Journal of Physiology. Cell Physiology 278 C92-C101.

Parfenova H, Neff RA III, Alonso JS, Shlopov BV, Jamal CN, Sarkisova SA \& Leffler CW 2001 Cerebral vascular endothelial heme oxygenase: expression, localization, and activation by glutamate. American Journal of Physiology. Cell Physiology 281 C1954-1963

Park DW, Cho T, Kim MR, Kim YA, Min CK \& Hwang KJ 2003 ATP-induced apoptosis of human granulosa luteal cells cultured in vitro. Fertility and Sterility $80993-1002$.

Peluso JJ, Pappalardo A \& Fernandez G 2001 E-Cadherin-mediated cell contact prevents apoptosis of spontaneously immortalized granulosa cells by regulating Akt kinase activity. Biology of Reproduction 64 1183-1190.

Peluso JJ, Bremner T, Fernandez G, Pappalardo A \& White BA 2003 Expression pattern and role of a 60-kilodalton progesterone binding protein in regulating granulosa cell apoptosis: involvement of the mitogen-activated protein kinase cascade. Biology of Reproduction $\mathbf{6 8}$ $122-128$.

Quirk SM, Cowan RG, Joshi SG \& Henrikson KP 1995 Fas antigen-mediated apoptosis in human granulosa/luteal cells. Biology of Reproduction 52 279-287.

Quirk SM, Harman RM \& Cowan RG 2000 Regulation of Fas antigen (Fas, CD95)-mediated apoptosis of bovine granulosa cells by serum and growth factors. Biology of Reproduction 63 1278-1284.

Santana P, Llanes L, Hernandes I, Gallardo G, Quintana J, Gonzalez J, Estevez F, Galarreta CR \& Fanjul LF 1995 Ceramide mediates tumor necrosis factor effects in P450-aromatase activity in cultured granulosa cells. Endocrinology 136 2345-2348.

Stuhlmeier KM 2000 Activation and regulation of Hsp32 and Hsp70. European Journal of Biochemistry 267 1161-1167.

Terry CM, Clikeman JA, Hoidal JR \& Callahan KS 1998 Effect of tumor necrosis factor- $\alpha$ and interleukin- $1 \alpha$ on heme oxygenase expression in human endothelial cells. American Journal of Physiology. Heart and Circulatory Physiology 274 H883-H891.

Tilly JL, Kowalski KI, Johnson AL \& Hsueh AJW 1991 Involvement of apoptosis in ovarian follicular atresia and postovulatory regression. Endocrinology 129 2799-2801.

Van Voorhis BJ, Dunn MS, Snyder GD \& Weiner CP 1994 Nitric oxide: an autocrine regulator of human granulosa-luteal cell steroidogenesis. Endocrinology 135 1799-1806.

Villamor E, Pérez-Vizcaníno F, Cogolludo AL, Conde-Oviedo J, Zaragozá-Arnáez F, López-López JG \& Tamargo J 2000 Relaxant effects of carbon monoxide compared with nitric oxide in pulmonary and systemic vessels of newborn piglets. Pediatric Research 48 546-553.

Ye J \& Laychock SG 1998 A protective role for heme oxygenase expression in pancreatic islets exposed to interleukin- $1 \beta$. Endocrinology 139 4155-4163.

Yoshida T, Biro P, Cohen T, Müller RM \& Shibahara S 1988 Human heme oxygenase cDNA and induction of its mRNA by hemin. European Journal of Biochemistry 171 457-461.

Received 29 September 2003

Accepted 14 January 2004

Made available online as an

Accepted Preprint 20 January 2004 